\title{
53BP1 inhibits the migration and regulates the chemotherapy resistance of ovarian cancer cells
}

\author{
SHUHUI HONG ${ }^{1,2}$, XIAOYAN LI ${ }^{3}$, YING ZHAO ${ }^{1}$, QIFENG YANG ${ }^{3}$ and BEIHUA KONG ${ }^{1}$ \\ ${ }^{1}$ Department of Obstetrics and Gynecology, Qilu Hospital, Shandong University, Jinan, Shandong 250012; \\ ${ }^{2}$ Department of Gynecology, Affiliated Qianfoshan Hospital of Shandong University, Jinan, Shandong 250014; \\ ${ }^{3}$ Department of General Surgery, Qilu Hospital, Shandong University, Jinan, Shandong 250012, P.R. China
}

Received July 1, 2016; Accepted May 19, 2017

DOI: $10.3892 / 01.2018 .8596$

\begin{abstract}
The major problems faced during the treatment of ovarian cancer are metastasis and the development of intrinsic or acquired drug resistance. The present study assessed whether tumor protein p53 binding protein 1 (53BP1) regulated migration and modulated chemotherapy resistance in SKOV3 cells and identified proteins associated with the molecular mechanisms underlying this coordinate regulation. SKOV3 cells were transfected using a 53BP1-expressing vector, which induced 53BP1 overexpression. The migration of the transfected cells was observed using a Transwell assay. The expression of matrix metalloproteinase (MMP)-2 and MMP-9 were assayed using gelatin zymography. In addition, the effects of 53BP1 on the chemosensitivity of SKOV3 cells to cisplatin were evaluated using MTT and western blot assays. Compared with the control, the average number of migrating SKOV3/pLPC-53BP1 cells was decreased from $230 \pm 58$ to $45 \pm 12(\mathrm{P}<0.05)$ and the protein expression of MMP-9 was significantly inhibited. However, the chemosensitivity of SKOV3/pLPC-53BP1 to cisplatin decreased significantly: Cisplatin half maximal inhibitory concentration $\left(\mathrm{IC}_{50}\right)$ for SKOV3/pLPC-53BP1=7.58 $\pm 0.51 \mu \mathrm{g} / \mathrm{ml}$; cisplatin $\mathrm{IC}_{50}$ for control=2.98 $\pm 0.27 \mu \mathrm{g} / \mathrm{ml}(\mathrm{P}<0.01)$. Decreased chemosensitivity to cisplatin may be associated with increased expression of phosphorylated-protein kinase B and cyclin dependent kinase 2 and with decreased expression of $\mathrm{p} 21$ and the $\mathrm{B}$ cell lymphoma $(\mathrm{Bcl})-2$ associated $\mathrm{X} / \mathrm{Bcl}-2$ ratio. The results of the present study demonstrated that 53BP1 may inhibit migration but upregulate chemoresistance to cisplatin in SKOV3 cells.
\end{abstract}

Correspondence to: Dr Beihua Kong, Department of Obstetrics and Gynecology, Qilu Hospital, Shandong University, 107 Wenhuaxi Road, Jinan, Shandong 250012, P.R. China

E-mail: kongbeihua@sdu.edu.cn

Key words: tumor protein p53 binding protein 1, ovarian cancer, migration, cisplatin, chemoresistance

\section{Introduction}

In addition to the implementation of tumor cytoreductive surgery, the majority of patients with ovarian cancer require regular chemotherapy to remove residual small lesions. Though initially sensitive to chemotherapy, up to $80 \%$ of patients with ovarian cancer produce endogenous or acquired chemoresistance (1). The recurrence and metastasis of ovarian cancer results in poor prognosis. The 5-year survival rate for patients with advanced ovarian cancer is $34-39 \%$ (2).

Previous studies have demonstrated that epithelial ovarian cancer treatment improves with platinum-based combination chemotherapy compared with nonplatinum-based chemotherapy (3-5). Cisplatin is commonly used by gynecologists to kill tumor cells by inducing DNA damage, promoting cell cycle arrest and increasing the rate of apoptosis $(6,7)$. Previous studies have reported the following mechanisms underlying chemotherapy resistance: Certain tumor cells exhibit enhanced DNA repair functions and a weakened apoptotic process, with the transformation to epithelial stroma facilitating the secretion of matrix protein enzymes, including matrix metalloproteinase (MMP)-2 and MMP-9, which enable these tumor cells to break through the basement membrane, metastasize and invade. Therefore, chemoresistance and invasion are associated in tumor cells (8-12).

Tumor protein p53 binding protein 1 (53BP1), an adaptor/mediator protein, is a cytologic marker of endogenous doublestranded DNA damage (13-15). 53BP1 is primarily associated with DNA damage response activation, which maintains the stability of genetic information within the cell. However, Lai et al (11) studied the clinical and biological significance of 53BP1 and demonstrated that increased expression of 53BP1 was associated with increased resistance to cisplatin and worsened prognosis in lung adenocarcinomas. To the best of our knowledge, no research has focused on the effects of 53BP1 on migration and chemoresistance in ovarian cancer. The present study assessed the modulation of 53BP1 expression level in the ovarian cancer cells SKOV3, and recorded alterations in cell metastasis and chemotherapy sensitivity.

\section{Materials and methods}

Reagents. Lipofectamine 2000, RPMI-1640 medium and puromycin were purchased from Invitrogen; Thermo 
Fisher Scientific, Inc. (Waltham, MA, USA). N-Myc-proto-oncogene (MYC)-53BP1-wild type (WT) pLPC-Puro plasmids were obtained from Addgene, Inc. (Cambridge, MA, USA). The N-MYC-WT pLPC-Pruo plasmid was obtained from the Laboratory of Cell Biology and Genetics of Rockefeller University (New York, NY, USA). The enhanced chemiluminescence (ECL) kit used for western blot analysis and the gel electrophoresis device were acquired from GE Healthcare Bio-Sciences (Pittsburgh, PA, USA). The antibodies against protein kinase B (Akt; 1:1,000; cat. no. 9272), phosphorylated (p)-Akt (1:1,000; cat. no. 4060), B cell lymphoma (Bcl)-2 (1:1,000; cat. no. 2872), Bcl-2 associated X (Bax; 1:1,000; cat. no. 2772), p21 (1:1,000; cat. no. 2947), cyclin dependent kinase 2 (CDK2; 1:1,000; cat. no. 2546) and $\beta$-actin (1:1,000; cat. no. 4970) were purchased from Cell Signaling Technology, Inc. (Danvers, MA, USA). Cisplatin was purchased from Sigma-Aldrich; Merck KGaA.

Cell culture and transfection. The human ovarian cancer cell line SKOV3 was obtained from the American Type Culture Collection (Manassas, VA, USA). The cells were cultured in RPMI-1640 supplemented with $10 \%$ fetal bovine serum (FBS; Tianjin Haoyang Biological Products Technology Co., Ltd., Tianjin, China) in accordance with the supplier's protocol. The cells were transfected with N-MYC-proto-oncogene-53BP1-WT pLPC-Puro and N-MYC-WT pLPC-Pruo using Lipofectamine 2000 according to the manufacturer's protocol. Endogenous 53BP1 overexpression was induced in SKOV3 cells using N-MYC-53BP1 WT PLPC-Puro plasmids. Cells were selected for overexpression in complete RPMI-1640 medium containing $1.5 \mu \mathrm{g} / \mathrm{ml}$ puromycin at $37^{\circ} \mathrm{C}$. Cells that survived for 10 days were named SKOV3/pLPC-53BP1 (as the experimental group) or SKOV3/pLPC-vector (as the control group). The efficiency of transfection was confirmed using western blot analysis as subsequently described.

Transwell migration assay. SKOV3/pLPC-53BP1 and SKOV3/pLPC-vector cells $\left(1 \times 10^{7}\right.$ cells/ml, $\left.100 \mu \mathrm{l}\right)$ were resuspended in RPMI-1640 medium without FBS and placed into the coated membrane of the upper chamber of Transwell plates. RPMI-1640 supplemented with 20\% FBS was used as an attractant in the lower chamber. Following incubation at $37^{\circ} \mathrm{C}$ for $24 \mathrm{~h}$, migratory cells located on the lower side of the chamber were fixed in methanol (at room temperature for $15 \mathrm{~min}$ ) and then stained with $0.2 \%$ crystal violet (at room temperature for $15 \mathrm{~min}$ ). The stained cell images were captured using a light microscope and 10 random fields at magnification, x10 were counted. Results represented the average of triplicate samples from three independent experiments.

Gelatin zymography analysis. Gelatinolytic activity was induced in the cell culture supernatant of SKOV3/pLPC-53BP1 and SKOV3/pLPC-vector cells via SDS-PAGE with a $10 \%$ gel containing $1 \mathrm{mg} / \mathrm{ml}$ gelatin (Invitrogen; Thermo Fisher Scientific, Inc.). Following incubation in renaturation buffer (2.5\% Triton X-100 at room temperature for $45 \mathrm{~min}$ ) and development buffer (pH 7.6, Tris. $\mathrm{HCl} 6.06 \mathrm{~g}, \mathrm{CaCl}_{2} 0.56 \mathrm{~g}$, $\mathrm{NaCl} 11.688 \mathrm{~g}, \mathrm{ZnCl}_{2} 0.136 \mathrm{mg}, \mathrm{ddH}_{2} \mathrm{O}$ up to $\left.1,000 \mathrm{ml}\right)$ at $37^{\circ} \mathrm{C}$ for $18 \mathrm{~h}$, the gels were stained using Coomassie Brilliant Blue R-250 (Bio-Rad Laboratories, Inc.), and destained in a mixture of acetic acid and methanol at room temperature every 5 min until a colorless enzyme band showed. Relative quantities of protein were measured using a densitometer (ImageJ software v1.48, National Institutes of Health, Bethesda, ML, USA). All procedures were performed in duplicate.

Drug sensitivity assay. An MTT assay was performed to assess the sensitivity of SKOV3/pLPC-53BP1 cells to cisplatin; SKOV3/pLPC-vector cells served as the control. Cells were seeded onto 96-well plates in RPMI-1640 medium with $10 \%$ FBS $\left(4.0 \times 10^{3}\right.$ cells/well; final volume=200 $\left.\mu \mathrm{l}\right)$. Following attachment to the plates, cells were exposed to $0,0.4,0.8,1.6$, $3.2,6.4,12.8$ or $25.6 \mu \mathrm{g} / \mathrm{ml}$ cisplatin for $72 \mathrm{~h}$ at $37^{\circ} \mathrm{C}$ in a $5 \% \mathrm{CO}_{2}$ incubator. Subsequently, $20 \mu 1$ MTT ( 5 mg/ml; Sigma-Aldrich; Merck KGaA) was added to each well and wells were incubated for a further $4 \mathrm{~h}$ at $37^{\circ} \mathrm{C}$. The medium was then removed and $150 \mu 1$ dimethyl sulfoxide was added to each well. Absorbance of each well at $490 \mathrm{~nm}$ was read using a microplate reader. The half maximal inhibitory concentration $\left(\mathrm{IC}_{50}\right)$ of each drug was estimated from the relative survival curves. Independent experiments were performed three times in 5 duplicate wells. Mitochondrial activity, which may reflect cellular growth and viability, was evaluated by measuring optical density (OD) at $490 \mathrm{~nm}$ on a microtiter plate reader. The relative survival rate was calculated as follows:

$$
\begin{aligned}
& \text { Relative survival rate }(\%)=\left(\mathrm{OD}_{\text {treated }}-\mathrm{OD}_{\text {zero setting }}\right) / \\
& \left(\mathrm{OD}_{\text {control }}-\mathrm{OD}_{\text {zero setting }}\right) \times 100 \% \text {. }
\end{aligned}
$$

Western blot analysis. The SKOV3/pLPC-53BP1 cells that were maintained in $0,0.4,0.8$ or $1.6 \mu \mathrm{g} / \mathrm{ml}$ cisplatin for $72 \mathrm{~h}$ were harvested. Whole-cell lysates were prepared by incubating cells in RIPA buffer (Shennengbocai, Shanghai, China; $1 \%$ NP-40,0.1\% SDS, 5 mM EDTA, $0.5 \%$ sodium deoxycholate, $1 \mathrm{mM}$ sodium vandate) containing protease inhibitors $(1 \mathrm{mM}$ phenylmethane sulfonyl fluoride and $1 \mathrm{mM}$ sodium fluoride) on ice for $30 \mathrm{~min}$. Cell lysates were centrifuged at 8,000 $\mathrm{x}$ g for $15 \mathrm{~min}$ at $4^{\circ} \mathrm{C}$. The supernatant was subsequently collected and the protein concentration was measured using a BCA Protein Assay kit (Merck KGaA). A total of $50 \mu \mathrm{g}$ proteins were separated using $8 \%$ SDS-PAGE and transferred onto polyvinylidene fluoride membranes (EMD Millipore, Billerica, MA, USA). The membranes were blocked using 5\% non-fat milk for $1 \mathrm{~h}$ at room temperature and then incubated with primary antibodies, including Akt, p-Akt, Bcl-2, Bax, p21, CDK2 and $\beta$-actin overnight at $4^{\circ} \mathrm{C}$. The membranes were then washed three times with TBST and subsequently incubated with horseradish peroxidase-conjugated secondary antibodies (1:5,000; cat. no. 5210-0174; Kirkegaard and Perry Laboratories Inc., Gaithersburg, MD, USA) at room temperature for $2 \mathrm{~h}$. Bands were detected with an enhanced chemiluminescence detection system (cat. no. NEL102001EA; PerkinElmer Inc., Waltham, MA, USA). ImageJ software (version 1.48; National Institutes of Health, Bethesda, ML, USA) was used for the densitometric analysis of western blotting.

Statistical analysis. Data were expressed as the mean \pm standard deviation. Statistical comparisons between groups of normally 

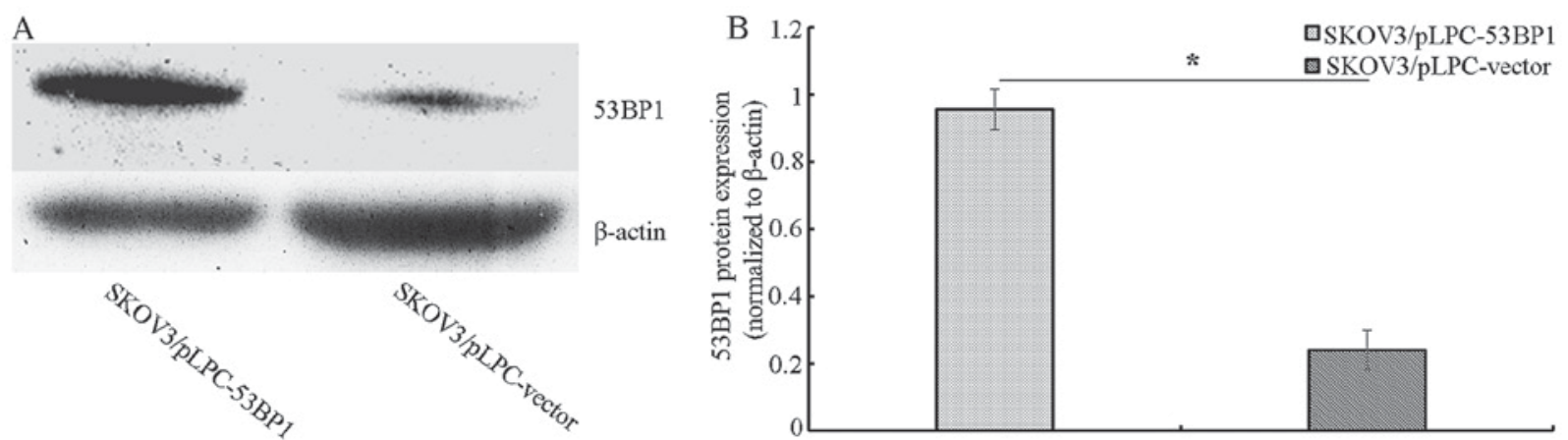

Figure 1. Protein expression of 53BP1 in modified ovarian cancer cells. (A) 53BP1 expression in SKOV3/pLPC-53BP1 and SKOV3/pLPC-vector cells was evaluated using western blot analysis. $\beta$-actin served as a loading control. (B) Relative expression of 53BP1 protein in ovarian cancer cells. Data were represented as the mean \pm standard deviation. $\beta$-actin was a normalization control. ${ }^{*} \mathrm{P}<0.05$ vs. control. 53BP1, tumor protein p53 binding protein 1 .

distributed data were performed using the Student's t-test via SPSS version 16.0 (SPSS, Inc., Chicago, IL, USA). P $<0.05$ was considered to indicate a statistically significant difference.

\section{Results}

Evaluation of 53BP1 protein expression in ovarian cancer cells following transfection with 53BPl-overexpressing plasmids. Stable transfected cell lines were generated by expanding the resistant colonies, including SKOV3/pLPC-53BP1 and SKOV3/pLPC-vector transfected cell lines. The expression of 53BP1 in these cell lines was assessed using western blot analysis. SKOV3/pLPC-53BP1 cells exhibited increased 53BP1 expression compared with SKOV3/pLPC-vector cells (Fig. 1A and $\mathrm{B})$.

53BP1 ectopic expressiondecreasesmigrationin SKOV3-derived cell lines. To determine the effect of 53BP1 on SKOV3 migration, Transwell assays were performed. SKOV3/pLPC-53BP1 cells exhibited a significant decrease in migration compared with SKOV3/pLPC-vector cells $(\mathrm{P}<0.05)$. The number of migratory SKOV3/pLPC-53BP1 cells was $45.00 \pm 12.00$, compared with $230.00 \pm 58.00$ migratory SKOV3/pLPC-vector cells $(\mathrm{P}<0.05$; Fig. 2A-C). Therefore, the present study demonstrated that 53BP1 significantly decreased migration in SKOV3 cells.

53BP1 decreases MMP-associated proteolytic activity. Using gelatin zymography, the effect of 53BP1 on MMPs was evaluated. SKOV3/pLPC-vector cells (gray value $=18.17 \pm 2.13$ ) exhibited increased MMP-9 activity compared with SKOV3/pLPC-53BP1 cells (gray value $=7.94 \pm 1.12$; Fig. $2 \mathrm{D}-\mathrm{F}$ ). However, the two types of cell exhibited no difference in the activity of MMP-2.

Evaluation of cisplatin-associated antitumor activity using an MTT assay. The cytotoxicity of cisplatin in SKOV3/pLPC-53BP1 and SKOV3/pLPC-vector cells was evaluated using an MTT assay. SKOV3/pLPC-vector cells $\left(\mathrm{IC}_{50}=2.98 \pm 0.27 \mu \mathrm{g} / \mathrm{ml}\right)$ were demonstrated to be more sensitive to $0.4-6.4 \mu \mathrm{g} / \mathrm{ml}$ cisplatin compared with SKOV3/pLPC-53BP cells $\left(\mathrm{IC}_{50}=17.58 \pm 0.51 \mu \mathrm{g} / \mathrm{ml}\right.$; Fig. $\left.3 \mathrm{~A}\right)$.

Western blot analysis. When culturing cells without cisplatin, increased 53BP1 expression was associated with the upregulation of proteins associated with the inhibition of apoptosis, including Bax, p21 and the Bax/Bcl-2 ratio, However, with the downregulation of proliferation-promoting proteins, including p-Akt, Bcl-2 and CDK2 (Fig. 3B-F), SKOV3/pLPC-53BP1 cells exposed to $0.4-1.6 \mu \mathrm{g} / \mathrm{ml}$ cisplatin exhibited a decrease in the protein expression of $\mathrm{Bax} / \mathrm{Bcl}-2$ and $\mathrm{p} 21$ compared with SKOV3/pLPC-vector cells (Fig. 3B, D and F, respectively). For treatment with $0.8-1.6 \mu \mathrm{g} / \mathrm{ml}$ cisplatin, the expression of $\mathrm{p}-\mathrm{Akt}$ and CDK2 was increased in SKOV3/pLPC-53BP1 compared with SKOV3/pLPC-vector cells (Fig. 3C and E, respectively).

\section{Discussion}

Despite the progress in cancer treatment and the understanding of tumor biology, ovarian cancer remains one of the most lethal gynecologic malignancies (16). Further study is required to resolve aggressive behavior and drug resistance in ovarian cancer, which are major challenges to developing more effective therapies. The BRCA1 C-Terminal domain-containing 53BP1, a p53-binding protein, is associated with the regulation of the cell cycle and DNA damage response (17-19). Previous studies have demonstrated that following knockdown of 53BP1, mice exhibited growth retardation, radiotherapy sensitivity and tumor susceptibility $(20,21)$. Furthermore, 53BP1 may attenuate the expression of p-Akt and Bcl-2, increase the protein expression of Bax and the $\mathrm{Bax} / \mathrm{Bcl}-2$ ratio, and induce cell cycle arrest and apoptosis, resulting in decreased proliferation, in SKOV3 cells (22). To further assess the effects of 53BP1 on SKOV3 cells, the present study evaluated migration and chemosensitivity to cisplatin in 53BP1-overexpressing SKOV3 cells.

During metastasis, cancercells receive signals from the tumor microenvironment and undergo an epithelial-mesenchymal transition, which decreases tumor polarity and cell-cell adhesion (23). Furthermore, cancer cells may secret proteinases to degrade multiple components of the extracellular matrix and thereby enhance migration and metastasis (24). The extracellular matrix and basement membrane are barriers inhibiting metastasis. The degradation of the extracellular matrix by metastatic cancer cells is associated with multiple proteolytic enzymes, including MMPs and cathepsins (25,26). Typically, increased cancer aggression is associated with increased MMP secretion by the cancer (27).

In the present study, MMP-9 expression was downregulated by 53BP1 overexpression compared with the control, resulting in the inhibition of migration in SKOV3 cells (Fig. 2). However, 
A

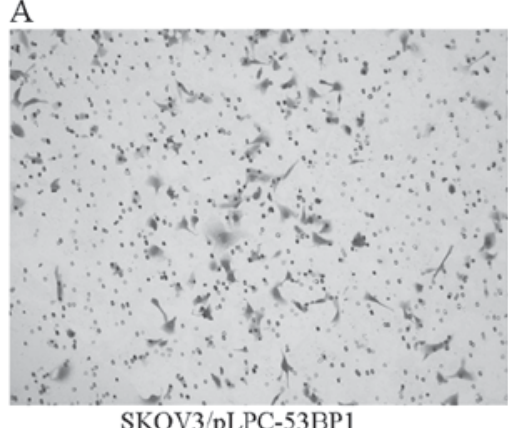

B
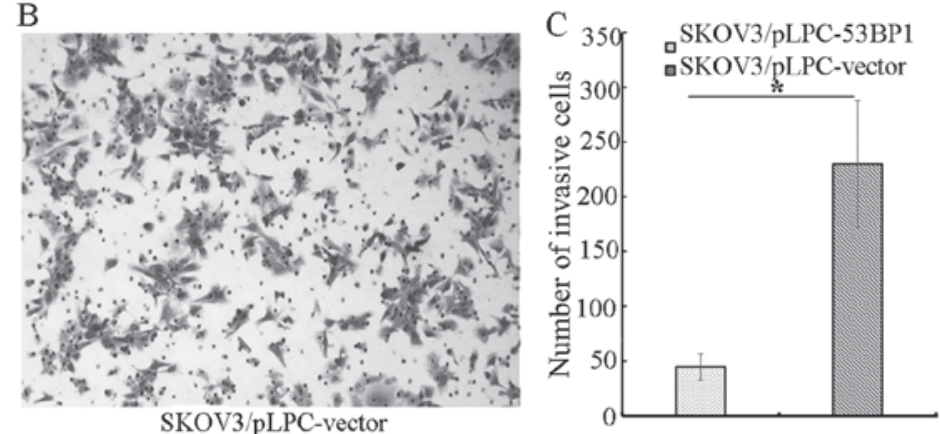

$\mathrm{D}$
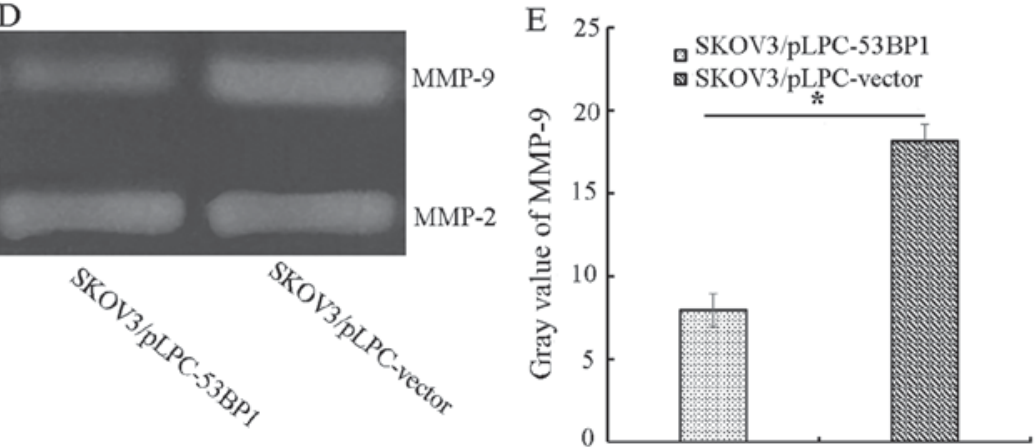

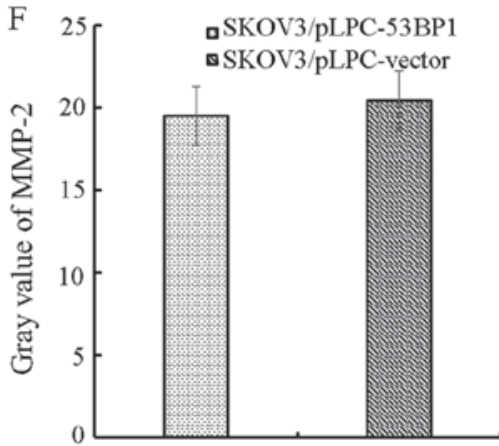

Figure 2. Transwell assay reveals that cell migration is inhibited by 53BP1 overexpression. (A) Representative image of migratory SKOV3/pLPC-53BP1 cells (magnification, x10). (B) Representative image of migratory SKOV3/pLPC-vector cells (magnification, $\mathrm{x} 10$ ). (C) Compared with migratory SKOV3/pLPC-vector cells, the mean number of migratory SKOV3/pLPC-53BP1 cells was decreased from $230 \pm 58$ to $45 \pm 12(\mathrm{P}<0.05)$. (D) MMP-9 and MMP-2 activity were assessed using gelatin zymography. (E) Compared with that in SKOV3/pLPC-vector cells, the protein expression of MMP-9 in SKOV3/pLPC-53BP1 cells was significantly inhibited and (F) the protein expression of MMP-2 was not significantly altered. Data were represented as the mean \pm standard deviation. " $\mathrm{P}<0.05$ vs. control. 53BP1, tumor protein $\mathrm{p} 53$ binding protein 1; MMP, matrix metalloproteinase.
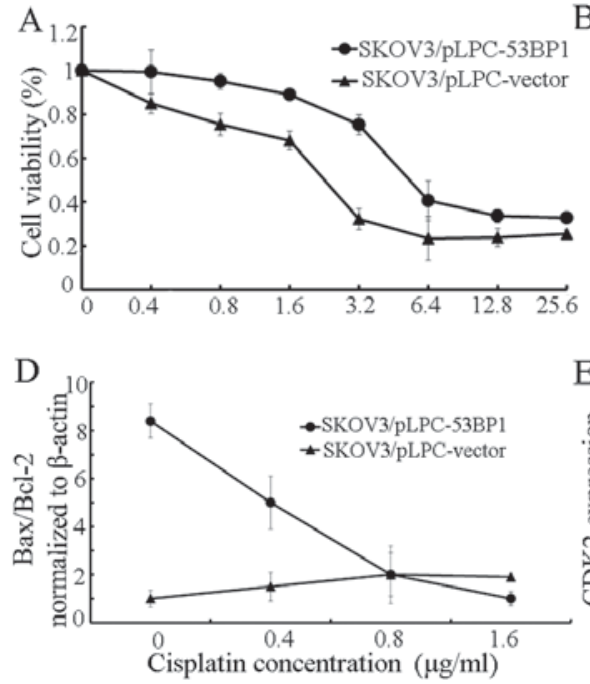

B

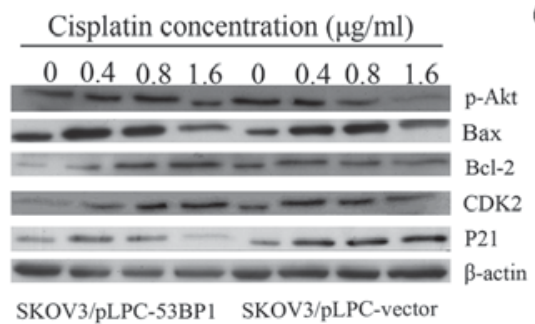

$\mathrm{E}$

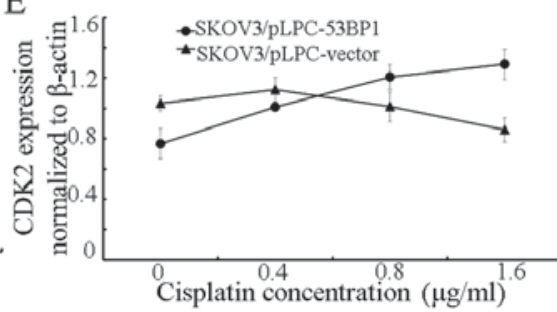

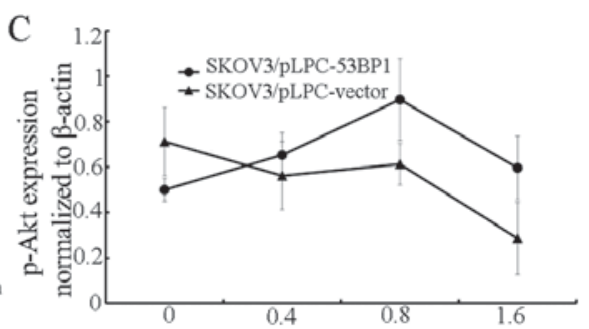

$\mathrm{F}$

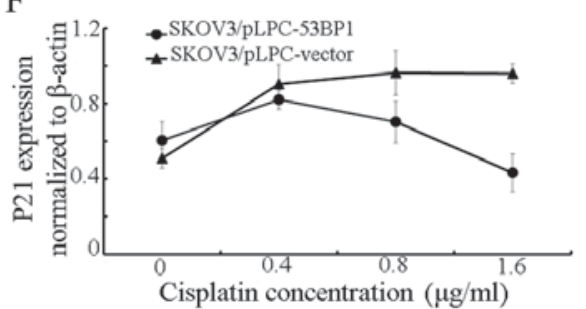

Figure 3. Expression of 53BP1 is associated with cisplatin chemoresistance. (A) Cell viability was assayed following treatment with an increasing concentration of cisplatin for $72 \mathrm{~h}$. (B) Expression of p-Akt, Bax, Bcl-2, CDK2 and p21 in SKOV3/pLPC-53BP1 and SKOV3/pLPC-vector cells following treatment with $0,0.4,0.8,1.6 \mu \mathrm{g} / \mathrm{ml}$ cisplatin was assessed using western blot analysis. $\beta$-actin served as a loading control. The relative expression of (C) p-Akt, (D) Bax/Bcl-2, (E) CDK2 and (F) p21 in SKOV3/pLPC-53BP1 and SKOV3/pLPC-vector cells. $\beta$-actin was a normalization control. Data were represented as the mean \pm standard deviation. 53BP1, tumor protein p53 binding protein 1; p-Akt, phosphorylated protein kinase B; Bax, Bcl-2 associated X; Bcl-2, B cell lymphoma-2; CDK2, cyclin dependent kinase 2.

no statistically significant difference in MMP-2 expression was demonstrated between groups. These results suggested that 53BP1 decreased the metastatic potential of SKOV3 cells by inducing the downregulation of MMP-9. Further study is required to determine the 53BP1-associated pathway that facilitated MMP-9 attenuation.
Certain tumor invasion-regulating genes are associated with numerous characteristics of tumor biology, including drug sensitivity and the induction of angiogenesis (28). Drug resistance remains a substantial challenge to successfully treating ovarian cancer. Cisplatin is an effective chemotherapeutic agent for the treatment of ovarian cancer. The present study evaluated the 
effect of 53BP1 on the chemosensitivity of SKOV3 cells to cisplatin. SKOV3 cells overexpressing 53BP1 and cultured without cisplatin exhibited decreased viability compared with control cells cultured without cisplatin, a result consistent with those of a previous study (22). However, increased 53BP1 expression was associated with increased cisplatin resistance in SKOV3 cells. With particular respect to the $0.4-1.6 \mu \mathrm{g} / \mathrm{ml}$ cisplatin treatment, 53BP1 expression was associated with resistance to cisplatin.

Resistance to cisplatin is associated with multiple complex system properties, and the underlying mechanism remains to be fully understood. Previously, Bcl-2, p-Akt, p21, Bax and CDK2 have been demonstrated to be associated with chemotherapy resistance in multiple types of tumor $(22,29)$. The present study therefore proposed that these proteins may also be associated with 53BP1-induced chemotherapy resistance in SKOV3 cells. The present study demonstrated that treatment with $0.4-1.6 \mu \mathrm{g} / \mathrm{ml}$ cisplatin resulted in a decreasing trend in the protein expression of $\mathrm{Bax} / \mathrm{Bcl}-2$ and $\mathrm{p} 21$; an increasing tendency in the expression of p-Akt and CDK2 in SKOV3/pLPC-53BP1 was also observed at $0.4-1.6 \mu \mathrm{g} / \mathrm{ml}$ cisplatin, compared with SKOV3/pLPC-vector cells. The Akt signaling pathway is associated with $\mathrm{Bax} / \mathrm{Bcl}-2$-mediated cell survival and the phosphorylation of the Thr145 and Ser146 residues of p21, which renders the protein incapable of entering the nucleus from the cytoplasm (30). Increased active CDK2 expression promotes p21 degradation and thereby facilitates p21 repression. Thus, decreased expression of $\mathrm{p} 21$, a tumor suppressor, may combine with increased CDK2 expression to promote cell survival (31).

However, a consensus on the effects of 53BP1 on cellular responses to chemotherapeutic agents has yet to be reached, with multiple studies having demonstrated increased or decreased drug sensitivity with 53BP1 overexpression $(11,32,33)$. These conflicting reports suggest that the association between 53BP1 and chemosensitivity may be more complex than previously assumed.

To conclude, the present study revealed that 53BP1 suppressed SKOV3 cell migration by decreasing MMP-9 expression. However, the present study also suggested that 53BP1 promoted cisplatin chemoresistance, a function associated with decreased Bax/Bcl-2 and p21 expression and increased p-Akt and CDK2 expression. Although the mechanism underlying 53BP1-induced chemoresistance remains to be understood, a potential underlying mechanism for future studies to evaluate is DNA repair.

\section{Acknowledgements}

Not applicable.

\section{Funding}

The present study was supported by the Projects of Medical and Health Technology Development Program (grant no. 2015WS0242).

\section{Availability of data and materials}

The datasets generated and/or analyzed during the present study are available from the corresponding author on reasonable request.

\section{Authors' contributions}

BK designed the study. SH performed experiments, participated in statistical analysis and drafted the manuscript. SH, XL, YZ and QY assisted with experiments and manuscript preparation. All authors read and approved the final manuscript.

\section{Ethics approval and consent to participate}

Not applicable.

\section{Consent for publication}

Not applicable.

\section{Competing interests}

The authors declare that they have no competing interests.

\section{References}

1. Li J, Yang S, Su N, Wang Y, Yu J, Qiu H and He X: Overexpression of long non-coding RNA HOTAIR leads to chemoresistance by activating the $\mathrm{Wnt} / \beta$-catenin pathway in human ovarian cancer. Tumour Biol 37: 2057-2065, 2016.

2. Musella A, Marchetti C, Palaia I, Perniola G, Giorgini M, Lecce F, Vertechy L, Iadarola R, De Felice F, Monti M, et al: Secondary cytoreduction in Platinum-resistant recurrent ovarian cancer: A Single-institution experience. Ann Surg Oncol 22: 4211-4216, 2015.

3. Gabra H: Introduction to managing patients with recurrent ovarian cancer. EJC Suppl 12: 2-6, 2014.

4. Du XL, Parikh RC, Lairson DR, Giordano SH and Cen P: Comparative effectiveness of platinum-based chemotherapy versus taxane and other regimens for ovarian cancer. Med Oncol 30: 440, 2013.

5. Pinato DJ, Graham J, Gabra H and Sharma R: Evolving concepts in the management of drug resistant ovarian cancer: Dose dense chemotherapy and the reversal of clinical platinum resistance. Cancer Treat Rev 39: 153-160, 2013.

6. Vendetti FP, Lau A, Schamus S, Conrads TP, O'Connor MJ and Bakkenist CJ: The orally active and bioavailable ATR kinase inhibitor AZD6738 potentiates the anti-tumor effects of cisplatin to resolve ATM-deficient non-small cell lung cancer in vivo. Oncotarget 6: 44289-44305, 2015.

7. Zhu S, Pabla N, Tang C, He L and Dong Z: DNA damage response in cisplatin-induced nephrotoxicity. Arch Toxicol 89: 2197-2205, 2015.

8. Wang L, Mosel AJ, Oakley GG and Peng A: Deficient DNA damage signaling leads to chemoresistance to cisplatin in oral cancer. Mol Cancer Ther 11: 2401-2409, 2012.

9. Schiewer MJ, Goodwin JF, Han S, Brenner JC, Augello MA, Dean JL, Liu F, Planck JL, Ravindranathan P, Chinnaiyan AM, et al: Dual roles of PARP-1 promote cancer growth and progression. Cancer Discov 2: 1134-1149, 2012.

10. Johannessen TC, Prestegarden L, Grudic A, Hegi ME, Tysnes BB and Bjerkvig R: The DNA repair protein ALKBH2 mediates temozolomide resistance in human glioblastoma cells. Neuro Oncol 15: 269-278, 2013.

11. Lai TC, Chow KC, Lin TY, Chiang IP, Fang HY, Chen CY and Ho SP: Expression of 53BP1 as a cisplatin-resistant marker in patients with lung adenocarcinomas. Oncol Rep 24: 321-328, 2010.

12. Zhu B, Block NL and Lokeshwar BL: Interaction between stromal cells and tumor cells induces chemoresistance and matrix metalloproteinase secretion. Ann N Y Acad Sci 878: 642-646, 1999.

13. Fukuda T, Wu W, Okada M, Maeda I, Kojima Y, Hayami R, Miyoshi Y, Tsugawa K and Ohta T: Class I histone deacetylase inhibitors inhibit the retention of BRCA1 and 53BP1 at the site of DNA damage. Cancer Sci 106: 1050-1056, 2015. 
14. Li J and Xu X: DNA double-strand break repair: A tale of pathway choices. Acta Biochim Biophys Sin (Shanghai) 48: 641-646, 2016.

15. Zimmermann $\mathrm{M}$ and de Lange T: 53BP1: Pro choice in DNA repair. Trends Cell Biol 24: 108-117, 2014.

16. Jemal A, Bray F, Center MM, Ferlay J, Ward E and Forman D: Global cancer statistics. CA Cancer J Clin 61: 69-90, 2011.

17. Schultz LB, Chehab NH, Malikzay A and Halazonetis TD: p53 binding protein 1 (53BP1) is an early participant in the cellular response to DNA double-strand breaks. J Cell Biol 151: 1381-1390, 2000.

18. Rappold I, Iwabuchi K, Date T and Chen J: Tumor suppressor p53 binding protein 1 (53BP1) is involved in DNA damage-signaling pathways. J Cell Biol 153: 613-620, 2001.

19. Chai YL, Cui J, Shao N, Shyam E, Reddy P and Rao VN: The second BRCT domain of BRCA1 proteins interacts with p53 and stimulates transcription from the $\mathrm{p} 21 \mathrm{WAF} 1 / \mathrm{CIP} 1$ promoter. Oncogene 18: 263-268, 1999.

20. Markova E, Vasilyev S and Belyaev I: 53BP1 foci as a marker of tumor cell radiosensitivity. Neoplasma 62: 770-776, 2015

21. Morales JC, Xia Z, Lu T, Aldrich MB, Wang B, Rosales C, Kellems RE, Hittelman WN, Elledge SJ and Carpenter PB: Role for the BRCA1 C-terminal repeats (BRCT) protein 53BP1 in maintaining genomic stability. J Biol Chem 278: 14971-14977, 2003.

22. Hong S, Li X, Zhao Y, Yang Q and Kong B: 53BP1 suppresses tumor growth and promotes susceptibility to apoptosis of ovarian cancer cells through modulation of the Akt pathway. Oncol Rep 27: 1251-1257, 2012.

23. Fischer KR, Durrans A, Lee S, Sheng J, Li F, Wong ST, Choi H, El Rayes T, Ryu S, Troeger J, et al: Epithelial-to-mesenchymal transition is not required for lung metastasis but contributes to chemoresistance. Nature 527: 472-476, 2015.

24. Christiansen JJ and Rajasekaran AK: Reassessing epithelial to mesenchymal transition as a prerequisite for carcinoma invasion and metastasis. Cancer Res 66: 8319-8326, 2006.

25. Nicolson GL: Tumor and host molecules important in the organ preference of metastasis. Semin Cancer Biol 2: 143-154, 1991.
26. Dass K, Ahmad A, Azmi AS, Sarkar SH and Sarkar FH: Evolving role of uPA/uPAR system in human cancers. Cancer Treat Rev 34: 122-136, 2008

27. Pârvănescu V, Georgescu M, Georgescu I, Surlin V, Pâtrascu S, Picleanu AM and Georgescu E: The role of matrix metalloproteinase-9 (MMP-9) as a prognostic factor in epithelial and lymphatic neoplasia. Chirurgia (Bucur) 110: 506-510, 2015.

28. Lee JH, Chiang SY, Nam D, Chung WS, Lee J, Na YS, Sethi G and Ahn KS: Capillarisin inhibits constitutive and inducible STAT3 activation through induction of SHP-1 and SHP-2 tyrosine phosphatases. Cancer Lett 345: 140-148, 2014.

29. Michaud WA, Nichols AC, Mroz EA, Faquin WC, Clark JR, Begum S, Westra WH, Wada H, Busse PM, Ellisen LW and Rocco JW: Bcl-2 blocks cisplatin-induced apoptosis and predicts poor outcome following chemoradiation treatment in advanced oropharyngeal squamous cell carcinoma. Clin Cancer Res 15: 1645-1654, 2009.

30. Zhou BP, Liao Y, Xia W, Spohn B, Lee MH and Hung MC: Cytoplasmic localization of p21Cip1/WAF1 by Akt-induced phosphorylation in HER-2/neu-overexpressing cells. Nat Cell Biol 3: 245-252, 2001.

31. Ghanem L and Steinman R: A Proapoptotic function of p21 in differentiating granulocytes. Leuk Res 29: 1315-1323, 2005.

32. Li X, Kong X, Kong X, Wang Y, Yan S and Yang Q: 53BP1 sensitizes breast cancer cells to 5-fluorouracil. PLoS One 8: e74928, 2013.

33. Pan S, Cheng L, White JT, Lu W, Utleg AG, Yan X, Urban ND, Drescher CW, Hood L and Lin B: Quantitative proteomics analysis integrated with microarray data reveals that extracellular matrix proteins, catenins, and p53 binding protein 1 are important for chemotherapy response in ovarian cancers. OMICS 13: 345-354, 2009. 